\title{
CONCEPTUALISATION INDICES IN HEALTH AND LIFE SCIENCES TRANSLATION: AN EXPERIENTIALIST APPROACH
}

\author{
Sylvie Vandaele \\ Université de Montréal \\ sylvie.vandaele@umontreal.ca
}

\begin{abstract}
Conceptual metaphors, as theorized by George Lakoff, are essential to scientific and biomedical thought. They express themselves in speech through metaphorical expressions. Understanding conceptual metaphors is critical for translators. Several years ago we proposed the concept of conceptualization index, which is the linguistic element by which metaphor operates. This article begins with a description of the experiential framework used for a number of studies realized in biomedicine and life sciences. Then, the predicative, quasi-predictive, and non-predictive conceptualization indices are distinguished. Finally, the general principles deduced from the set of data are presented.
\end{abstract}

\section{Résumé}

Les métaphores conceptuelles, telles que les a théorisées George Lakoff, sont fondamentales pour la pensée scientifique. Elles s'expriment en discours par l'intermédiaire d'expressions métaphoriques. Comprendre les métaphores conceptuelles est donc essentiel pour les traducteurs. Nous avons proposé, il y a plusieurs années, le concept d'indice de conceptualisation, qui est l'élément linguistique par lequel opère la métaphore. Le présent article commence par préciser le cadre expérientialiste dans lequel se situent les travaux présentés. Puis, les indices de conceptualisation prédicatifs, quasi-prédicatifs et non prédicatifs sont distingués. Enfin, les principes tirés de l'ensemble des données recueillies sont présentés.

Keywords: Conceptualisation index. Conceptual metaphor and metonymy. Fictive and factive representations. Predicative and non-predicative units. Quasi-predicative unit. 
Second Keywords: Indice de conceptualization. Métaphore et métonymie conceptuelles. Unités prédicatives ou non-prédicatives. Unités quasi-prédicatives. 


\section{Introduction}

Despite the rise of computer-assisted translation, mastering highly specialized translation still remains a challenge, particularly in the rapidly evolving domains such as biomedicine and life sciences. On the one hand, translators will have to work more and more with computer-generated pre-translations and then provide their clients with post-edited texts which, hopefully, will be free of any error. Hence, translators will have to deal with what appears to be the most difficult part of the translation process: evaluating the validity of the machine's output, correcting any errors, and handling the most difficult, unresolved problems. On the other hand, a large number of documents deal with new subjects or are very complex. In these cases, the efficiency of computer-assisted translation, which relies on huge corpora, drops dramatically. Therefore, it may be anticipated that, more than ever, a keen knowledge of what underlies biomedical and life sciences texts will be necessary if a translator is to be successful: terms and concepts, idiomaticity and phraseology, grammatical rules as well as specific practices but, above all, various conceptualizations found in modern science and biomedicine.

What I intend here by "conceptualizations" is clearly explained by Geeraerts and Cuyckens in the framework of cognitive linguistics:

Linguistic structures are thought to express conceptualizations, that is, conceptualization is central for linguistic structure-and conceptualization goes further than mere reference. It involves imagery in the broadest sense of the word: ways of making sense, of imposing meaning (Geeraerts \& Cuyckens 2012/2010: online).

Since Lakoff and Johnson (1980/2003), metaphorical conceptualization is fundamental in exploring the relationships between thought and language. For translators, the understanding of conceptual metaphors and their linguistic counterparts in the discourse is paramount: Lakoff and co-workers have emphasized the pervasive nature of conceptual metaphorization on our everyday lives (Lakoff $\&$ Johnson 1980/2003), but there is no reason to believe that any human experiential and knowledge domain would be an exception. 
Indeed, it has now been well established that life sciences and biomedical discourse is often metaphorical, which applies to both specialized and popularized discourse in various languages (see Vandaele 2000, and other subsequent articles e.g. Vandaele 2003a, 2003b, 2004, 2009, 2013; van Rijn-van Tongeren 1997; Fox-Keller 1999 Temmerman 2000; 2002; Collombat 2003; Oliveira 2009). This is also true of other disciplines, such as economics and finance (e.g. Boers \& Demecheleer 1997; Rojo Lopez 2011), business (Koller 2004), politics (Lakoff 2008), education (Cameron 2003), physics (Mirowski 1989/2001), etc., not the least being translatology/translation studies (D'hulst 1992). In science, the heuristic and conceptualizing value of metaphors has been clearly demonstrated. While some still lament the presence of metaphors in science, I believe that those individuals may not have grasped the fact that metaphors are impossible to avoid because there is no other viable alternative that would be as efficient and economical. Those individuals might also tend to envision metaphors as "deviant"; however, the rise of cognitive semantics, more specifically experientialism, has shown that metaphors are deeply rooted in our minds.

However, metaphors still represent a true challenge for the translator: should he/she transfer the same metaphor into the target culture and language? Find another one and, if so, which one? Or should he/she, if possible, neutralize it? In this work, I intend to provide a synthesis of a study ${ }^{1}$ on conceptual metaphor in health and life sciences, a project that started in 2000, and the results of which have been published mostly in French. I will nonetheless provide the reader with new insights, notably concerning the particular case of quasi-predicates as metaphorical conceptualization indices. In the end, I hope that the reader will have in hand a comprehensive approach to scientific metaphor, an approach that will be useful for the translation field, be it teaching, research or actual practice.

The first question is: what is a metaphor? Much has been written on this subject; however, I feel that I should still clarify my postulates. As noticed by Samaniego Fernández (2011), metaphor has been under the scrutiny of a

1. The research presented here has involved students who participated as research assistants $\left({ }^{*}\right)$ or in the context of their Master's thesis ( $\$$ ): Marie-Claude Béland* (en-fr), EveMarie Gendron-Pontbriand $\downarrow$ (en-fr; 2013) Mariane Gingras-Harvey (en-fr-de; 2014), Mélanie Labelle (en-fr; 2009); Leslie Lubin* (en-fr; 2005), Paula F. Malaszkiewics (fr-pt [Brasil]; 2015), Julie Mondoux* (en-fr), Mariana Raffo* (en-fr-es; 2014), Bruna Steffen $\downarrow$ (fr-pt [Brasil]; 2016. The corpora that were used in the different studies were: specialized textbooks and monographs, scientific articles and, in certain cases, some popularization journals such as Scientific American. The references are extensively described in the articles cited in the reference section. 
number of translation researchers, leading to "three basic positions [...]: (1) metaphors are untranslatable [...]; (2) metaphors are fully translatable, just like any other translation issue [...] and (3) metaphors are translatable but pose a considerable degree of inequivalence [...]." (Samaniego Fernández 2011: 263-264) However, most of the time, metaphor is understood as a matter of a deviant use of a word, either as a literary stylistic device, or as a rhetorical instrument. However, if, as a biologist, I say "the cells intend to commit suicide", fellow biologists will not take it as fancy daydreaming, rather they will instantly understand that I am referring to the concept of apoptosis ${ }^{2}$, which has been described in the specialized literature as the process of "cell suicide". It is not a deviant usage of the word, nor a rhetorical device: researchers need to rely on what is accessible to them to describe what they observe in their laboratory or in the field. It means that the cell seems "to make the decision" to die according to a "program" as opposed to passively dying due to an injury (cell necrosis). It is very difficult to express this phenomenon in non-metaphorical words (see Almeisen 2003 for this particular example, cited in Vandaele 2009). In fact, to say that the cell "makes a decision", "commits suicide" or "functions according to a program" is very common in the scientific literature and is not the hallmark of popularized discourse ${ }^{3}$. The question here is not to decide whether a particular metaphorical linguistic expression is translatable or not, it is rather to grasp the whole conceptualization that lies behind it (not only in the source text, but also in a particular scientific domain); to determine the extent of this conceptualization in the scientific frame of thought; and, finally to be able to select the most appropriate linguistic tools (the words) in the target language to render this conceptualization.

What theoretical tools are useful to understand and describe scientific metaphors? In my previous line of work in biomedical research, I experienced strong influences which determined the theoretical framework which I later decided to follow in my translation and terminology research (see Vandaele

2. "One of the mechanisms by which CELL DEATH occurs (compare with NECROSIS and AUTOPHAGOCYTOSIS). Apoptosis is the mechanism responsible for the physiological deletion of cells and appears to be intrinsically programmed. It is characterized by distinctive morphologic changes in the nucleus and cytoplasm, chromatin cleavage at regularly spaced sites, and the endonucleolytic cleavage of genomic DNA; (DNA FRAGMENTATION); at internucleosomal sites. This mode of cell death serves as a balance to mitosis in regulating the size of animal tissues and in mediating pathologic processes associated with tumor growth." Medical Subject Headings, NCBI. (https://www. ncbi.nlm.nih.gov/mesh/68017209)

3. As explained by Wright (2011) and Raffo (2016), popularized texts and highly specialised texts are on a continuum. No clear-cut categorisation can be made. 
2007 for more details). My epistemological references are rooted in neuroscience, more precisely in the idea that consciousness emerges from neuronal functioning. Over the last 30 years or so, a number of neurobiologists, such as Gerald Edelman in the United States (e.g. Edelman 1987, 1992, 2006) or Jean-Pierre Changeux ${ }^{4}$ in France (Changeux 1983/2012), have been strong proponents of a neuronal theory of thought, postulating that innate potentialities are modulated by retroactions induced through the acquisition processes during development. These approaches underline the importance of epigenetic factors (i.e. the influence of the environment on a living being) to try to explain how consciousness emerges from the biological organization of the brain and the body. This means that objectivist and essentialist theories are immediately rejected. Edelman claims that his theory of consciousness "takes as its canonical reference our own experience as humans and our ability to report that experience by language" (Edelman 1992: 225). At the same time, he advocates for the existence of a real world independent from human conceptualizations. Consequently, he refers to Lakoff's experientalist theory as the linguistic theory that parallels his own.

The main statement of experientialism is that experience is the source of knowledge. As Geeraerts and Cuyckens explained,

Also, the conceptualizations that are expressed in the language have an experiential basis, that is, they link up with the way in which human beings experience reality, both culturally and physiologically. In this sense, Cognitive Linguistics embodies a fully contextualized conception of meaning (Geeraerts \& Cuyckens 2010: online).

According to Lakoff and coworkers, experientialism is a "myth" that transcends the fundamental opposition between the objectivist and subjectivist "myths":

The fact that the myths of subjectivism and objectivism have stood for so long in Western cultures indicates that each serves some important function. [...]

The fundamental concern of the myth of objectivism is the world external to the individual. The myth rightly emphasizes the fact that there are real

4. For recent and fascinating comments by Changeux about his book and modern neuroscience, see his conference "Lhomme neuronal, trente ans après" (Colloque interdisciplinaire de la République des Savoirs, 17 octobre 2014, <https://www.youtube.com/ watch?v=vY3DY2xA53w>).

5. Lakoff and Johnson use the word "myth" to designate a pervasive way of thinking, such as objectivism or subjectivism: "Incidentally, we are not using the term 'myth' in any derogatory way. Myths provide ways of comprehending experience; they give orders to our lives" (Lakoff \& Johnson 1980/2003: 185). It could very well be replaced by "theoretical foundation". 
things, existing independently of us, which constrain both how we interact with them and how we comprehend them. [...]

What legitimately motivates subjectivism is the awareness that meaning is always meaning to a person. What's meaningful to me is a matter of what has significance for me. And what is significant for me will not depend on my rational knowledge alone, but on my past experiences, values, feelings, and intuitive thoughts (Lakoff \& Johnson 1980/2003: 226-227).

The authors continue, explaining that the experientalist "myth" reconciles the two lines of thought: postulating that the source of knowledge starts with the experiences of our body in its environment, "scientific knowledge is still possible" (Lakoff $\&$ Johnson 1980/2003: 227) and, at the same time,

[...] it gives an account of how understanding uses the primary resources of the imagination through metaphor and how it is possible to give experience new meaning and to create new realities.

Where experientialism diverges from subjectivism is in its rejection of the Romantic idea that imaginative understanding is completely unconstrained.

In summary we see the experientialist myth as capable of satisfying the real and reasonable concerns that have motivated the myths of both subjectivism and objectivism but without either the objectivist obsession with absolute truth and the subjectivist insistence that imagination is totally unrestricted (Lakoff \& Johnson 1980/2003 : 228).

These premises are not new, but I feel that it is necessary to come back to them. First, because of the primacy of reality, it places the experientalist approach on a different line of thought than the subjectivist approach, in particular extreme constructivism. Second, it is a prerequisite for the shared intersubjectivity that is necessary to allow for the existence of language, communication among humans. Finally, translation is a problem for objectivists. For different reasons, subjectivism and objectivism do not provide any integrative framework in which it is possible to envision the various dimensions of translation. Objectivism hardly takes into account the wide variety of cultures and languages, tending to model language on the basis of a computer metaphor (see the criticisms of generative linguistics in Notari 2010). As Leddy states (1995: 206), "[o]bjectivists believe in absolute truths and universally valid knowledge. Objectivism is associated with a wide range of philosophers, linguists, psychologists, and cognitive scientists (e.g. Frege, Husserl, Chomsky, Russell, Searle \& Davidson)". In such views, metaphors in science are a real problem because, for these authors, imagination should not take place in the process of describing and understanding the world; this task should be perfectly literal and objective: "Objectivists see metaphorical truth as a fiction" (Leddy 1995: 207). In the case of subjectivism, heirs of Romanticism (and in translation 
studies, of Schleiermacher, such as Berman) do not even consider scientific and technical texts as... texts (see, for a detailed criticism, Vandaele 2015). The extreme consequence of subjectivism is that it becomes impossible to communicate and, thus, to translate.

However, we do translate, e pur si muove. ${ }^{6}$ I agree with Lakoff and coworkers that a "middle path" is strongly needed to avoid the pitfalls of both objectivism and subjectivism. Experientialism seems to pave the way for it; more specifically, in translation, it allows us to explore on the same ground and with equal consideration what the human mind can produce, from literature to scientific texts. Also, a middle path between objectivism and subjectivism makes translation possible (although difficult), because if we recognize features shared among language-cultures, we must also confront those that remain specific, i.e. that which forms the bulk of translation problems. Delving further into controversies is not the scope of this work, and for the present purpose, I will concentrate on conceptual metaphor. I will also try to propose a useful framework for understanding, studying and translating them.

\section{From experientialism to conceptual metaphor and conceptualization indices}

The hallmark of Lakoff's work, which comes from his experientialist premises, is the idea of conceptual metaphor. He and Johnson made a breakthrough when they published Metaphors We Live By (Lakoff \& Johnson 1980/2003; see also Lakoff 1993 for an update). This book has been translated into numerous languages $^{7}$, is widely cited and has provided a theoretical frame for a wide range of studies. According to Leddy, "[...] experientialists have developed the most important implications of metaphor studies for philosophy so far" (Leddy 1995: 207). The fundamental idea is that we metaphorically conceptualize a large part of our world - including time - primarily on the basis of our bodily experience in the surrounding environment. Furthermore, metaphorical conceptualizations, as well as categorizations of entities and situations, are strongly culture-dependent (see Women, Fire and Dangerous Things [Lakoff 1987] for a fascinating analysis of the Dyirbal language and culture in Australia). This accounts for a number of shared conceptualizations among humans, as well as cultural specificities based on time and space. Therefore, I believe that

6. "Albeit it does move" (And yet it moves), attributed to Galileo (1564-1642).

7. 1st editions in French and Spanish: 1986; followed by other reprints or editions. Do note that the original 2nd edition in English, published in 2003, contains an important afterword (pp. 243-274) that does not always appear in the translations. 
this approach is fertile ground for translatology, and specifically for scientific translation.

Lakoff convincingly shows that a conceptual metaphor shows up in a number of metaphorical linguistic expressions. His examples are very well known (see e.g. ARGUMENT IS WAR or TIME IS MONEY metaphors, Lakoff \& Johnson 1980/2003: 5), therefore I will provide the reader with examples found in biomedical and life sciences texts. According to Lakoff's rules, conceptual metaphors are provided in small capitals (CELLS ARE PERSONS), while the metaphorical expressions are written in italics (The suicide of cells is called apoptosis). The lexical item that carries the metaphor is suicide (See Vandaele 2009 for a discussion about the circulation of conceptual metaphors in society).

The identification of a conceptual metaphor starts with collecting coherent metaphorical expressions. The metaphorical expression itself is identified thanks to a cognitive dissonance ${ }^{8}$ experienced by the subject and generated by the coexistence of a factive representation ("more" veridical) and a fictive representation ("less" veridical) (Talmy 2000: 101; 135-137).

Although Lakoff very clearly explains that, in his views, metaphors reside at the thought level (this is why it is called conceptual metaphor) and are linguistically expressed in metaphorical expressions, some confusion may still be observed in a number of texts dealing with metaphor. In particular, conceptual metaphors are not rhetorical devices (although metaphorical expressions can be used intentionally with rhetorical purposes), nor a stylistic feature (although original metaphorical expressions in literature reveal a conceptualization of the world that is specific to an author). Therefore, since conceptual metaphor is of primary importance in understanding and describing scientific concepts and objects, it is very important to exclude any metalinguistic items that could refer to rhetoric or style, such as tropes or figurative language. It is fundamental to separate a metaphor's nature and its role in a particular discourse. I therefore looked for a linguistically-based characterization of metaphorical expressions that would free up their study along other axis.

When analyzing metaphorical expressions, it is clear that, in each case, a specific lexical unit is the "carrier" of the conceptual metaphor'. Lubin and

8. I use the term cognitive dissonance without any reference to social psychology. I simply want to underline that the subject experiences a lack of coherence at the cognitive level. This experience varies in intensity: it may require an effort, notably for conceptual metaphors that are pervasive in a particular context. However, it may be that our concept shares some similarity with that of social psychology.

9. This is what Black (1962) calls focus (see Vandaele 2009 for a review of other terminology such as topic, vehicle, tenor, and in French, theme and phore). 
I called the linguistic elements that generate the cognitive dissonance: metaphorical conceptualization indices (indices de conceptualization métaphorique; Vandaele \& Lubin 2005). Semantically, metaphorical conceptualization indices found in metaphorical expressions as described by Lakoff are predicative lexical units $^{10}$. It can be a verb (the artery runs along the bone), a descriptive (qualifying or classifying) adjective (a guilty virus) or a deverbal noun ${ }^{11}$ (receptor), but very rarely an adverb.

Let's examine some examples:

The external carotid artery begins opposite the upper border of the thyroid cartilage, and, taking a slightly curved course, passes upward and forward [...]. [...] From its origin under the anterior border of the Sternocleidomastoideus it runs upward and forward for a short distance in the carotid triangle [...]. (Gray 1918: 3a. 2.)

Conceptualisation indices are, in the English example, begins, course, passes, runs, and in French, monte, traverse, pénètre. Similar indices referring to a seemingly fictive motion can be observed for nerves and veins (see Lubin 2005 for a detailed study of verbs in anatomy). We do know that neither the nerves, the arteries nor the veins are moving: we know that they are motionless and this corresponds to the factive representation. But at the same time we accept the fictive motion, so as to represent the fact that they are elongated structures located along, or in, other anatomical structures. Talmy (2000/2003) explains that, in his opinion, this kind of representation comes from the fact that the gaze follows the shape of the conceptualized entity (a fence, in his article), which creates an illusion of motion.

Like Lakoff, I believe that the use of conceptual metaphor is generally not consciously driven in everyday life. However, it can also be deliberately used to fulfill various goals: rhetorical, pragmatic, heuristic, etc. Over time, coherent metaphorical expressions build correspondences (rather than projection; see Lakoff \& Johnson 1980/2003, postface) between a source domain of experience to a target domain, which are subsumed under a conceptual metaphor and, inversely, salient conceptual metaphors build and structure our view of the world. They are likely to generate metaphorical expressions as needed:

10. The definition of predicative lexical units and actants comes from Mel'čuk (see e.g. Mel'čuk 2004a; 2004b): 1) A predicative lexical unit is a unit whose meaning contains slots that are filled up in the discourse. The prototypes are verbs. 2) Actants correspond to the slots in a predicative meaning and can be compulsory or facultative.

11. Deverbal nouns are particularly problematic, because their description in the specialized dictionaries do not take into account their actants in a proper manner. See Vandaele and Raffo 2008a. 
there are constant comings and goings between the acquisition of conceptual metaphors when being learnt, their reuse and the production of new ones. It is a highly dynamic process that never ends and that can bring, at the social level, change or, to the contrary, resistance to change (see Almeisen 2003 for his comment on the difficulty cell biologists have accepting the concept of "cell suicide" as a normal physiological process). We could hypothesize that a kind of "Darwinian" cognitive selection process constantly operates from the personal to the social level, leaving "alive" the most frequent metaphors - but not necessarily the most obvious ones. Contrary to Ricœur ${ }^{12}$ (1975/1997) who qualifies shared, lexicalized, metaphorical expressions as "dead", the most "alive" metaphorical conceptualizations are those that are so deeply intertwined with the culture that they are not easily perceived anymore. On the other hand, any metaphorical hapax - called "métaphore vive" by Ricœur ${ }^{13}-$, whether literary or not, risks death at birth if the utterance remains unheard, unread or hidden, like a lost book in an obscure library. This is why translating old texts, whether literary or scientific, is so difficult; we cannot easily access the metaphorical conceptualizations that prevailed at that time (see Vandaele \& Béland 2012 for an account of lost hypotheses on hereditary units at the end of the $19^{\text {th }}$ century, hypotheses that appeared later to be wrong).

Finally, it does seem possible to translate the name of a conceptual metaphor, but in fact it is totally meaningless if it is not supported by evidence of corresponding metaphorical expressions in the target language. Indeed, as for the examples presented in Table 1, the same conceptual metaphor is supported by congruent sets of metaphorical expressions in French and Spanish.

One of the most interesting results that emerged from our research is that the richness of IC sets varies among languages. For example, in anatomy, to render the subcategory of fictive appearance for arteries, veins, nerves and muscles, we have 6 ICs in French, and 3 ICs in English (Table 2; Vandaele and Lubin 2009; Lubin 2005). While the verb to run is prevalent in English to express a general fictive motion, there are many more possibilities in French. Hence the translator should consider equivalent sets of ICs expressing the same conceptualization rather than translating word for word.

12. Incidentally, Ricœur is one of the philosophers who strongly disagreed with Changeux. See Changeux \& Ricoeur (1998/2000).

13. The English translation of the book's title is (sadly): The rule of metaphor. 
Table 1 - A Conceptual Metaphor Shared in French, English and Spanish ${ }^{14,15}$

\begin{tabular}{|l|l|l|l|}
\hline $\begin{array}{l}\text { Metaphorical } \\
\text { expressions }\end{array}$ & $\begin{array}{l}\text { [agent pathogène] } \\
\text { incriminé, coupable, } \\
\text { responsable, accusé, } \\
\text { suspecté } \\
\text { etc. }\end{array}$ & $\begin{array}{l}\text { suspected, guilty, } \\
\text { accused, responsible } \\
\text { [pathogen agent] } \\
\text { etc. }\end{array}$ & $\begin{array}{l}\text { culpable, inocente, } \\
\text { sospechoso, } \\
\text { responsable } \\
\text { [patógeno] } \\
\text { etc. }\end{array}$ \\
\hline Correspondences & $\begin{array}{l}\text { La cause est le } \\
\text { coupable } \\
\text { Le processus } \\
\text { pathologique est } \\
\text { l'énigme } \\
\text { Le patient est la } \\
\text { victime } \\
\text { Le chercheur ou } \\
\text { le médecin est le } \\
\text { détective }\end{array}$ & $\begin{array}{l}\text { The cause is the } \\
\text { culprit } \\
\text { The pathological } \\
\text { process is the } \\
\text { enigma } \\
\text { The patient is the } \\
\text { victim } \\
\text { The researcher } \\
\text { or doctor is the } \\
\text { detective }\end{array}$ & $\begin{array}{l}\text { La causa es el } \\
\text { culpable } \\
\text { El proceso de la } \\
\text { enfermedad es el } \\
\text { enigma } \\
\text { El paciente es la } \\
\text { víctima } \\
\text { El investigador } \\
\text { o el médico es el } \\
\text { detective }\end{array}$ \\
\hline CONCEPTUAL & $\begin{array}{l}\text { LA RECHERCHE DE } \\
\text { LA CAUSE D'UNE } \\
\text { METAPHOR }\end{array}$ & $\begin{array}{l}\text { THE SEARCH } \\
\text { FOR THE CAUSE } \\
\text { OF A DISEASE } \\
\text { UNE ENION EST } \\
\text { CRIMINELLE }\end{array}$ & $\begin{array}{l}\text { LA BÚSQUEDA DE } \\
\text { LA CAUSA DE UNA } \\
\text { ENFERMEDAD ES } \\
\text { INVESTINATION } \\
\text { CRIMINALSTIGACIÓN }\end{array}$ \\
\hline
\end{tabular}

Table 2 - Conceptualisation Indices for Nerves, Arteries, Veins and Muscle (fictive appearance) (adapted from Lubin 2005)
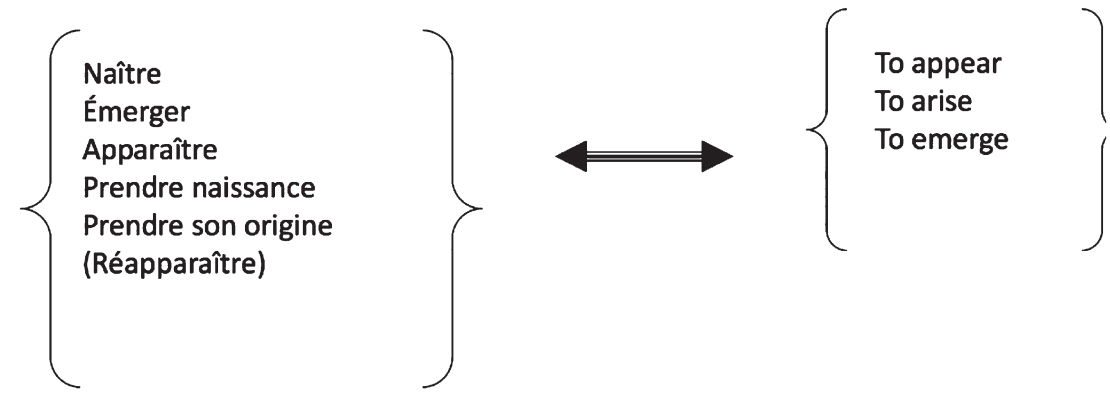

The metaphorical nature of idiomatic expressions explains that it is one the most important problems that translators and writers, and above all students, encounter. While denominations can be, most of the time, managed on the basis of the equivalence of the corresponding definitions in the source and

14. See Vandaele 2000: 398 for English and French.

15. For the sake of clarity and due to the lack of space, ICs attesting the other correspondences indicated in the table have not been included. See the articles for more details. 
target languages (i.e. equivalence of the genus and of the semantic traits), the choice of phraseologisms in the target language requires that we take into account the underlying metaphorical conceptualization. Since this involves more or less extended lexical networks (see Vandaele et al. 2006), confidence in the translation solutions is difficult to reach and grows slowly with experience. In this regard, using computerized tools is a pedagogical challenge, as it favors bypassing the processes of reading, understanding and thinking which are the basis for acquiring strong translation cognitive competences (for a discussion on some pitfalls of the use of Internet and computerized tools in the classroom, see Vandaele 2017).

\section{Conceptualisation indices and actantial analysis}

Although terminologists like Oliveira (2009) or Temmerman (2000; 2002) have focused mainly on metaphorical nouns/names (terms ${ }^{16}$ ), "Lakovian"17 metaphorical expressions often fall into the phraseologism category, which could be analyzed as collocates (Vandaele 2003b, 2004, 2005; Vandaele et al. $2006^{18}$; Barque \& Jousse 2006). However, complex names comprising a deverbal noun and/or a complex complement (dopamine receptor; récepteur à sept passages transmembranaires) also contain conceptualization indices (receptor; récepteur; passage). In fact, the key to understanding the underlying mechanism is that metaphorical conceptualization indices in "Lakovian" metaphorical expressions are predicative lexical units. This provides the clue to set up a systematic method of analysis in mono- and bilingual corpora (Vandaele $\&$ Lubin 2005).

Indeed, even before we coined the term conceptualization index, and relying on the powerful actancial analysis proposed by the Meaning-Text Theory (MTT) of Mel'čuk and coworkers (Mel'čuk 2004a; 2004b; 2012), I proposed that the metaphorical conceptualization operates through the projection of the actantial structure (in part or in full) of a source lexical unit onto a target

16. Although a number of theoretical approaches inspired by lexicology prefer to speak of "specialized lexical units" and would consider verbs and adjectives as terms, I prefer to refer to a more traditional definition of terminology as the "science of denominations", hence "terms" as "denominations". See below for further explanations. No approach is entirely satisfactory anyway.

17. Borrowed from Andor 2010: 157.

18. Although very attractive on a theoretical level, I have abandoned the use of MTT's lexical functions. They work best with meanings that can be easily generalized, as shown by the Magn function, which is quite rare in science. 
lexical unit (Vandaele 2003b; Vandaele 2004; 2005; see pénétrer in Figure 1) ${ }^{19}$. The two lexical units (source: $X$ [mobile entity] pénètre dans $Y$ par $Z$; target : $X$ [artery - immobile] pénètre dans Y par Z) belong to the same vocable, PÉNÉTRER. From a lexicological point of view, the use of a lexical unit as a conceptualization index creates a new meaning and, as exploited by Barque \& Jousse (2006), this provides a way to characterize the metaphorical links between a vocable's lexical units.

Figure 1 - Conceptualization Index and Actantial Structure

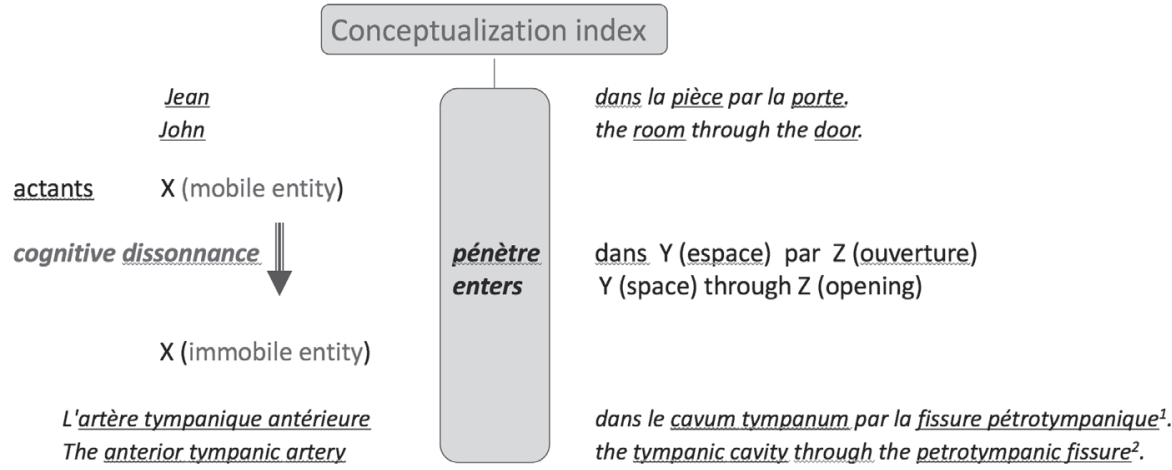

1. Dictionnaire médical de l'Académie de médecine.

2. Gray 1918 : Section 3a. 2. 8 (http://www.bartleby.com/107/144.html).

A predicate denotes a fact, a situation, a process and is generally ${ }^{20}$ characterized by a "binding meaning" (sens liant; Mel'čuk 2012: 195), "which is incomplete without other meanings that should be inserted into slots and thus 'bound together" (Mel'čuk 2012: 195). The other lexical units to be "inserted into the slots" of a predicate are called arguments, or actants. Non-predicative units that designate entities without arguments are called semantic names (e.g., protein, cell; molécule). Finally, quasi-predicates designate entities, but have at least one open slot (e.g. leg of a table, roof of the $4^{\text {th }}$ ventricle in the brain; piliers $d u$ cour; see below; Mel'čuk \& Polguère 2008).

19. The same hypothesis has been used later by Vidal and Cabré (2006) as well as Barque and Jousse (2006).

20. Mel'čuk insists on the fact that some predicates are semantically saturated and do not have open slots, as in it rains. These lexical units should not be confounded with semantic names. 
At the semantic level, the actantial structure of a predicative lexical unit is invariable and does not depend on the syntax in discourse, i.e., for verbs, the use of the active or passive voice. Even deverbal nouns have the same predicative structure as the verbs from which they derive.

It is necessary to examine several contexts to fully determine the actantial structure of a lexical unit (especially verbs and deverbal nouns) because some actants may be optional, i.e. not expressed in the text. Finally, optional actants must not be confused with circumstantials: actants fill meaning slots of predicates, while circumstantials do not. Consider the following: I eat an apple every morning. The verb to eat has two actants, expressed in this clause by $I$ (expressing the first semantic actant) and apple (expressing the second semantic actant); every morning is a circumstantial because its presence or its absence does not change the meaning of the verb (not to be confounded with the meaning of the sentence).

The MTT is extremely powerful for describing the meaning of lexical units in terms of their relations with other lexical units, their derivation and their collocates, finding a great application in lexicographic dictionaries, particularly for learners (Mel'čuk \& Polguère 2007).

Interestingly, we discovered in 2006 that Eco had proposed, 18 years earlier, to use case-based semantics to study metaphors:

Cependant la métaphore ne met pas en jeu que des similarités, mais aussi des oppositions. [...] Pour rendre compte de ces phénomènes, une représentation encyclopédique doit adopter le format d'une sémantique casuelle qui prenne en considération le Sujet Agent, l'Objet sur lequel l'agent exerce son action, [...] etc. Une telle sémantique a été élaborée par plusieurs auteurs (on peut penser aux « actants » de Tesnières et Greimas, aux « cas » grammaticaux de Fillmore, à la sémantique de Bierwisch). (Eco 1988/2006: 172-173)

Indeed Fillmore's Frames Semantics (see Andor 2010 for an interview with Fillmore, who reflects on his own theory) could have been the "natural" linguistic environment to analyze "Lakovian" metaphorical expressions (see Rojo Lopez 2011). However, the great advantage of the modelizing that the MTT offers over Frames semantics is that this latter does not clearly distinguish a lexical unit's true actants among the participants in a situation (called frame elements; see Alonso Ramos 2009 for a convincing comparison of the two theories $^{21}$ ). The fundamental problem is that working with corpora involves the

21. Setting apart actants and circumstantials is sometimes difficult, but Mel'čuk's principle is very clear: determining actants is critical in identifying the different lexical units that belong to a vocable, i.e. to account for polysemy. 
use of a semasiological strategy, i.e. to start from a text, which is constrained by the linguistic properties of words, to deduce conceptual knowledge.

Moreover, as Fillmore himself points out, Lakoff is using the concept of frames differently:

I distinguished cognitive frames from linguistic frames, the idea being that cognitive frames are those background understandings needed for making sense of things that happen around us, and linguistic frames are those that are specifically coded in - or "evoked by" - lexical units or other features of linguistic form. [...] George Lakoff emphasizes the frames that humans have by possessing human bodies, frames that are available for metaphoring, as well as the frames that humans acquire by living in a culture, frames that have different weightings or salience in their individual framicons [sic], allowing two people to have different interpretations of their experiences - or perhaps it would be more faithful to George's point of view to say that they have different experiences because of tendencies to frame experiences in different ways. (Fillmore, in Andor 2010: 158)

From my point of view, it is crucial, in the context of translation, to separate actants from circumstantials: if we admit that the basis for establishing linguistic equivalences between two predicative lexical units belonging to different languages is the identity of meaning, this can be done if, and only if, according to Mel'čuk's framework ${ }^{22}$, these units have a similar actantial structure, but not necessarily according to Fillmore's theory. However, comparing cognitive frames is also helpful in understanding the differences in the two languages-cultures in question, as it operates at a conceptual, encyclopedic level rather than at a lexical level. Zethsen rightly recalls that "equivalence is now regarded by most translation scholars as a flexible concept with many faces [...] and most scholars would not gainsay the fact that a professional translator must take the skopos of the translation into account and adjust the nature of the equivalence required accordingly" (Zethsen 2014:126)

However, also for this reason, I do not follow all the premises of the MTT, which focuses exclusively on semantic relationships between lexical units. Indeed we have to take into account the denominations (terms) formed by multilexical units in the actantial slots, for which the compositionality principle is not sufficient: we are more interested in the conceptualizations of, and the difference between, jugular artery and femoral artery, rather than by the compositional meaning of artery with either jugular or femoral; in other words, by the concepts or the referents rather than the meaning of lexical units. For this

22. For example, I eat and I eat an apple correspond to two lexical units ( $X$ eats and $X$ eats $Y$ ) or the vocable to eat. Then, $X$ eats could not be translated by $X$ mange $Y$. 
reason, Raffo and I (Vandaele \& Raffo 2008a) have distinguished the "lexical meaning" of lexical units from the "notional/conceptual meaning" of terms ${ }^{23}$. As a consequence, actantial slots of predicative lexical units can be filled by any monolexical or polylexical unit which refers to a concept (i.e. a term in the classical, non-lexicological, terminological approaches): in the sentence "the basilic vein joins the brachial vein", the conceptualization index is joins, and the first and the second actants are expressed, respectively, by basilic vein and brachial vein, rather than by vein.

Finally, to take advantage of the finely tuned analysis of predicative units, according to the MTT, and to allow the actantial slots to be filled by a syntagm referring to a concept, we follow, again, a "middle path" which combines, hopefully for the best and not for the worst, both lexical and terminological concepts. This is due to the fact that the analysis shown here is driven by corpora, and it must take into account the discourse as well as its referential aspect, and is intended to be useful in a translation context, while lexicology and terminology focus, respectively, on lexical units or terms with a lexicographical or terminolographical goal.

\section{Non-predicative conceptualization indices}

A number of conceptualization indices are non-predicative. This is the case, for example, for the noun cell in cell biology (see Table 3 for other examples).

The semantic mechanism involves a specific trait from the source concept that is attributed to the target one. For example, cell is a term that goes back to the $17^{\text {th }}$ century, when Robert Hooke, inspired by the shape of monastery "cells", named what he thought to be the basic unit of living organisms (the concept was right, but the structure he observed in his microscope was in fact small holes in cork bark, which were wrongly interpreted as vestiges of living cells; cited in Vandaele 2007). The trait projected from the monks' cells onto the cells of living organisms is the idea of a small, closed, delimited space. Traditionally, since Quintilien, it has been understood only as an extension of the meaning of a word (i.e. a catachresis: to use the noun cell to designate something other than the monk's small room that is not named yet), without referring to the motivation for this extension of meaning, i.e. the similar trait found in the two objects. It is often considered deviant, thus leading to confusion, by those who are hesitant about treating metaphors as a cognitive mechanism. Contrary to the predicative conceptualization indices, the origin

23. See also note 16. Two terms are said to be conotional when they refer to the same concept ("notion" in French). Synonymy is kept for lexical units having the same meaning. 
of the projection may be lost over time: it is very unlikely that the modern day biology reader keeps in his/her mind the origin of Hooke's act of denomination from four centuries ago. At best he/she will seize upon similar traits that are synchronically valid (the cell of the prisoner may now be more salient than a monk's cell), but the correspondence is likely to be lost, although not always (see the case of the olive in Figure 2). Typically, these units are discovered through an etymological analysis. In the medical field, a high number of specialised terms are formed using Greek or Latin roots (see below pons, fossa), carrying a metaphorical component, which are difficult to recognize without knowledge of these languages and a careful etymological analysis.

Table 3 - Examples of Non-predicative Conceptualization Indices

\begin{tabular}{|l|l|l|l|l|}
\hline \multicolumn{1}{|c|}{ Trait } & \multicolumn{2}{c|}{ English } & \multicolumn{2}{c|}{ French } \\
\hline shape & & Cell & cellule & \\
\hline $\begin{array}{l}\text { shape/ } \\
\text { function }\end{array}$ & & Pons & pont & \\
\hline shape & turcica $~$ & Sella & selle & $\sim$ turcique \\
\hline shape & & Trunk & tronc & \\
\hline shape & $\begin{array}{l}\text { accessory } \sim \text {, inferior } \sim \\
\text { superior } \sim, \text { cerebellar } \sim\end{array}$ & Olive & olive & $\begin{array}{l}\sim \text { accessoire, } \sim \\
\text { inférieure, } \sim \text { supérieure, } \\
\sim \text { cérébelleuse, }\end{array}$ \\
\hline shape & $\sim$ ovalis & Fossa & fosse & $\sim$ ovale \\
\hline
\end{tabular}

Figure 2 - Non-predicative Conceptualization Indices

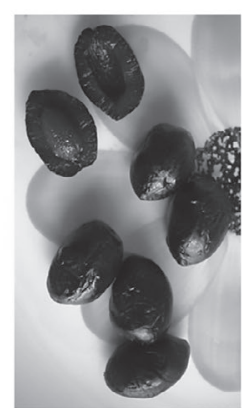

black olives $^{1}$

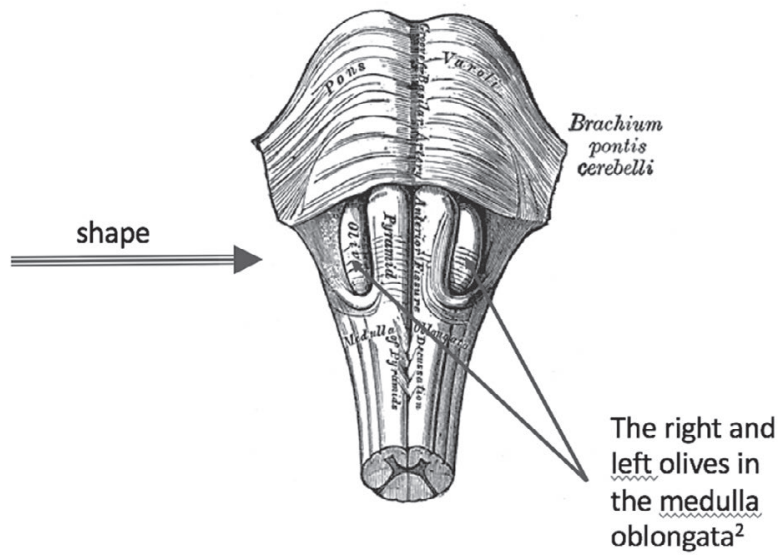

MonTI 10 (2018: 225-256). ISSN 1889-4178 


\section{Quasi-predicative Conceptualization Indices}

A lot of multi-lexical terms in anatomy contain quasi-predicates (Labelle 2009; Gingras-Harvey 2014; Vandaele et Gingras-Harvey 2014). Like semantic nouns, quasi-predicates denote entities, but like predicates, they cannot be described without actants (Mel'čuk \& Polguère 2008). The English term roof of the $4^{\text {th }}$ ventricle and the equivalent French term toit du 4 e ventricule (a brain structure) are examples: roof or toit are quasi-predicative, $4^{\text {th }}$ ventricle or $4^{e}$ ventricule are the actants, respectively. As for cell above, the trait projected from roof ${ }^{24}$ as a non-predicative unit onto roof [of the $4^{\text {th }}$ ventricle] is a specific characteristic, here a function (to cover a building or a vehicle), more or less associated to a shape (something flat). But, in addition, it is associated with an actant, $4^{\text {th }}$ ventricle.

Labelle (2009) and Gingras-Harvey (2014), in their Master's theses, have shown that anatomical and neuro-anatomical quasi-predicatives units are sourced from several fields of knowledge. Table 4 presents some examples of quasi-predicative ICs that are relevant to building parts, artefacts, plant parts or landscape metaphors. It should be noted that the actancial slot can be filled with a relational adjective which stands for a name (pelvic, plantaire). Also, the slot is not necessarily filled by a true actant (e.g. gouttière osseuse, as osseuse is at the same time a qualificative [or descriptive] and a relative [or classifying] adjective), leading to the idea that the predicative nature of lexical units is not so clear-cut and that predicative to non-predicative units form a continuum (Figure 3).

24. Roof: "The structure forming the upper covering of a building or vehicle. (New Oxford American Dictionary; electronic version for Macintosh; no publication date) 
Table 4 - Some quasi-predicative Conceptualization Indices in Anatomy ${ }^{25}$

\begin{tabular}{|c|c|c|c|c|}
\hline & \multicolumn{2}{|l|}{ English } & \multicolumn{2}{|l|}{ French } \\
\hline \multirow{8}{*}{$\begin{array}{l}\text { Building } \\
\text { parts }\end{array}$} & $\begin{array}{l}\text { mandibular } \sim, \\
\text { pelvic } \sim, \\
\text { vertebral } \sim, \\
\text { glossopalatine } \sim \ldots\end{array}$ & $\operatorname{arch}_{1}$ & $\operatorname{arc}$ & $\begin{array}{l}\sim \text { mandibulaire, } \\
\sim \text { pelvien, } \\
\sim \text { vertébral, } \\
\sim \text { glossopalatin... }\end{array}$ \\
\hline & foot & $\operatorname{arch}_{2}$ & voûte & $\sim$ plantaire \\
\hline & pleural & Dome & dôme & $\sim$ pleural \\
\hline & $\sim$ of the diaphragm & Cupola & coupole & $\sim$ diaphragmatique \\
\hline & vertebral & column & colonne & $\sim$ vertébrale \\
\hline & $\begin{array}{l}\sim \text { of the nose, } \\
\sim \text { of the mouth, } \\
\sim \text { of the } 4 \text { th } \\
\text { ventricle, } \\
\text { pelvic } \sim \ldots\end{array}$ & Floor & plancher & $\begin{array}{l}\sim \text { nasal, } \\
\sim \text { buccal, } \\
\sim \text { du } 4 \mathrm{e} \text { ventricule, } \\
\sim \text { pelvien }\end{array}$ \\
\hline & $\begin{array}{l}\sim \text { of the cranium, } \\
\sim \text { of the } 3 \mathrm{rd} \\
\text { ventricle, } \\
\sim \text { of the mooth, } \\
\sim \text { of the nose... }\end{array}$ & Roof & toit & $\begin{array}{l}\sim \text { crânien/du crâne, } \\
\sim \text { du 3e ventricule, } \\
\sim \text { buccal/de la bouche, } \\
\sim \text { nasal... }\end{array}$ \\
\hline & $\begin{array}{l}\text { neural } \sim, \\
\text { chiasmatic } \sim, \\
\text { lacrimal } \sim \ldots\end{array}$ & Groove & gouttière & $\begin{array}{l}\sim \text { neurale, } \\
\sim \text { chiasmatique, } \\
\sim \text { lacrymale... } \\
\end{array}$ \\
\hline Artefacts & $\begin{array}{l}\sim \text { of the obliquus } \\
\text { superior, patellar } \\
\sim \ldots\end{array}$ & Pulley & poulie & $\begin{array}{l}\sim \text { de l'oblique } \\
\text { supérieur, } \\
\sim \text { rotulienne/ } \\
\text { patellaire... }\end{array}$ \\
\hline & turcica & Sella & selle & $\sim$ turcique \\
\hline
\end{tabular}

25. I collected these examples from standard anatomy textbooks and atlases (e.g. from Gray's, Netter's, Feneis' or Rouvière's books). See Labelle 2009 and Gingras-Harvey 2014 for other examples on veins, arteries, nerves, muscles and brain structures in English, French and German. 


\begin{tabular}{|c|c|c|c|c|}
\hline \multirow{9}{*}{$\begin{array}{l}\text { Plant } \\
\text { parts }\end{array}$} & $\sim$ of vessels & Trunk & tronc & $\sim$ vasculaire \\
\hline & $\begin{array}{l}\text { brain } \sim \text {, } \\
\sim \text { of the left coronary } \\
\text { artery }\end{array}$ & Stem & tronc & $\begin{array}{l}\text { cérébral, } \\
\text { de l'artère coronaire } \\
\text { gauche }\end{array}$ \\
\hline & $\begin{array}{l}\sim \text { of arteries, } \\
\sim \text { of veins, } \\
\sim \text { of nerves, }\end{array}$ & Branch & rameau & $\begin{array}{l}\sim \text { artériel, } \\
\sim \text { veineux } \\
\sim \text { nerveux }\end{array}$ \\
\hline & $\begin{array}{l}\text { ovarian } \sim, \\
\text { hair } \sim\end{array}$ & follicle & follicule & $\begin{array}{l}\sim \text { pileux, } \\
\sim \text { ovarien }\end{array}$ \\
\hline & cerebellar & peduncle & pédoncule & cérébelleux \\
\hline & olfactive & Bulb & bulbe & $\sim$ olfactif \\
\hline & $\begin{array}{l}\text { bronchial } \sim \\
\text { vascular } \sim\end{array}$ & Tree & arbre & $\begin{array}{l}\sim \text { bronchique, } \\
\sim \text { vasculaire }\end{array}$ \\
\hline & $\sim$ of the ilium... & Spine & épine & $\sim$ iliaque... \\
\hline & $\begin{array}{l}\text { nerve } \sim \\
\sim \text { of the tooth... }\end{array}$ & Root & racine & $\begin{array}{l}\sim \text { nerveuse, } \\
\sim \text { dentaire... }\end{array}$ \\
\hline \multirow{5}{*}{ Landscape } & $\begin{array}{l}\text { abdominal } \sim, \\
\text { iliac } \sim \ldots\end{array}$ & Region & région & $\begin{array}{l}\text { abdominale, } \\
\sim \text { iliaque... }\end{array}$ \\
\hline & $\sim$ of sacrum & promontory & promonroire & $\sim$ du sacrum/sacré \\
\hline & pubic & Mons & mont & $\sim$ du pubis \\
\hline & inguinal canal & Canal & sillon & inguinal \\
\hline & $\begin{array}{l}\text { nasal } \sim \\
\text { iliac }\end{array}$ & Fossa & fosse & $\begin{array}{l}\sim \text { nasale, } \\
\sim \text { iliaque... }\end{array}$ \\
\hline
\end{tabular}

Figure 3 - From Predicative to Non-predicative Conceptualization Indices: a Continuum

dorsal spine selle turcique olive, olive pont pons colonne vertébrale roof of the 3rd ventricle fosse iliaque cloison nasale

However, conceptualization is part of the naming process: hence quasi-predicative CIs may remain "local" or they may form a thematically linked lexical network, but this network does not have the same "productivity" as the predicative network described above, or at least it does not operate at the same level. When the names of body parts come from the names of architectural entities, 
such as floor, pyramid, roof, column... it provides a general conceptualization of the brain or the body as a building. The major difference between predicative CIs and quasi-predicative CIs is the following: in the former, the metaphor operates indirectly: the source domain projects onto the target domain through the predicative IC; in the latter, the metaphor operates directly: the source domain projects onto the target domain through the denomination itself. A "quasi" actant is necessary to avoid an incorrect referential inference: the roof [of the $\underline{4}^{\text {th }}$ ventricle] is not really a roof (Figure 4).

Figure 4- Quasi-predicative conceptualization indices

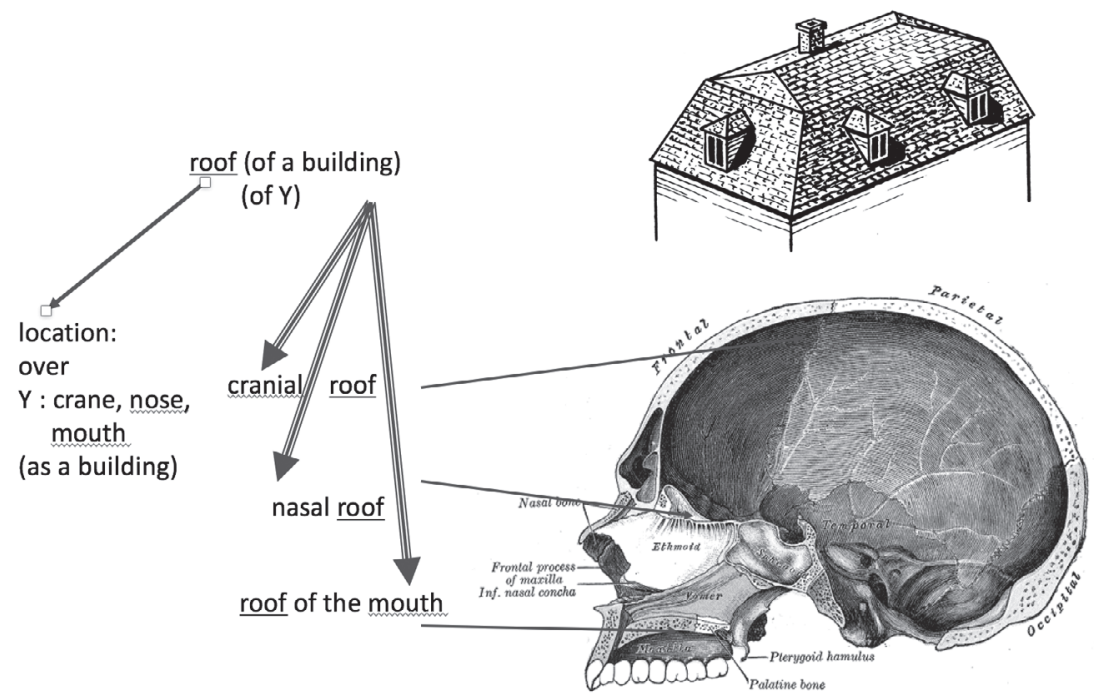

It should be emphasized that, in the case of non-predicative and quasi-predicative ICs, no lexical network reinforces the conceptualization of any specific entity: the metaphorical name informs the speaker about a property (the location, for example: mesencephalum roof, toit du mésencéphale). On the contrary, the accumulation of metaphorical expressions in which the conceptualized entity is expressed as an actant of various congruent predicative ICs reinforces a particular metaphorical conceptualization which then becomes productive: other ICs from the lexical network that underlies the metaphorical conceptualization can be used and this provides a powerful tool for popularizing scientific knowledge (see Vandaele \& Raffo 2008b). The strength of a metaphor conceptualizing an entity thus depends on the richness of the predicative IC set 
associated with the name of this entity, and it also depends on the frequency (number of occurrences) found in the texts.

\section{Properties of Metaphorical Conceptualization Indices and Translation: Conclusion}

After an extensive analysis of metaphorical conceptualization indices in various biomedical domains ${ }^{26}$ (clinical medicine, cellular biology, anatomy, neuroanatomy, history of genetics and theory of evolution - see note 2) and various languages (French, English, Spanish, Portuguese, German), a number of general statements can be made:

1) Conceptualization indices involved in a particular metaphorical concept form a stable lexical network (réseau lexical; see Vandaele et al. 2006 ${ }^{27}$; but see below). For example, conceptual metaphors used to describe the position of organs in anatomy are so stable that they are expressed in ancient texts, even written in Latin, e.g. by Vesalius in the $16^{\text {th }}$ century (Vesalius 1543, translated by Jacqueline Vons).

2) A conceptualization index can belong to several lexical networks (Vandaele et al. 2006).

3) Conceptualization indices may be grouped according to fictive representations (Talmy 2000; see Lubin 2006, Labelle 2009, GingrasHarvey 2014 for examples).

4) Idiomaticity is closely linked to the use of conceptualization indices shared by a community of locutors. This is related to the extent of translation readership.

5) However, these lexical networks are open sets. This means that creativity is a fundamental feature of metaphorical conceptualization, and that translators have at their hands various options, given the purposes of the source and target texts (cf. Christiane Nord and the functionalist school of translation). If a conceptual metaphor is culture-specific, it is possible to import the conceptualization into the target culture, or to use another conceptualization, either already existing or even

26. Comparable texts were used as much as possible. Some studies included parallel texts (reference books of anatomy or cell biology widely used in their translated version) or were specifically aimed at studying the translation of metaphorical expressions (hereditary units conceptualization, Vandaele and Béland 2012).

27. The idea of a lexical network is far from being new. It had notably expanded by the end of the seventies and is presently widely used by researchers using 3D-network representations of sets of lexical units. 
new. New insights and hypotheses in science represent an opportunity for neology and the creation of new conceptualization indices or even new conceptual metaphors (see Vandaele \& Béland 2012 for an analysis of the conceptual metaphors used to propose various models of hereditary units at the end of the $19^{\text {th }}$ century). However, we must keep in mind that a high number of metaphorical terms or expressions are strictly shaped by meaning and usage. Consequently, creativity is limited by usage and idiomaticity.

6) Some conceptualization are metaphtonymic (Goossens 1990). This can be demonstrated for la veine $X$ se jette dans la veine $Y$ (the vein $X$ throws itself into the vein $Y$ ) (Vandaele \& Lubin 2005). This means that a smaller vein $(\mathrm{X})$ is attached to a larger one $(\mathrm{Y})$. We have to remember that the blood goes from the smaller vein into the larger one. Therefore, what is evoked here is, at the same time, a fictive motion, the conceptualization of the vein as a stream or a river (metaphor), and the blood which actually "jumps" from one vessel to the next (metonymy).

7) In Spanish and in Portuguese, the verbs expressing the corresponding conceptual metaphor are homographs: desembocar (Malaszkiewics 2013; Malaszkiewics et al. 2015). The vein is still conceptualized as a river, but not as a "jumping" entity. It is a case where the translator must be careful not to transfer an inappropriate metaphor, for the sake of idiomaticity.

8) When a conceptual metaphor is shared among cultures-languages, the number of conceptualization indices expressing a certain meaning may be variable in each one, especially for predicative conceptualisation indices. Therefore, this opens up - or closes down - the translator's lexical choices.

9) In a given field of knowledge, an entity (either concrete or abstract) may be conceptualized through different conceptual metaphors. For example, in cell biology, cells are simultaneously conceptualized as animate entities, more specifically as persons, and as inanimate entities, e.g. as factories; molecules are simultaneously conceptualized as persons and as objects (see Vandaele 2000; Vandaele et al., 2006). Hence the coherence of the representations of the scientific objects is achieved through conceptual blending (Fauconnier \& Turner 1998).

10) Popularization discourse is often characterized by a higher density of conceptualization indices (see Vandaele $\&$ Raffo 2008b). Some are 
borrowed from more specialized discourses, others are dynamically expressed so as to help the reader grasp specialized concepts.

11) Popularization discourse may also be a place for creativity, albeit carefully: if the conceptual blending fails, the result may be even more difficult to grasp than the specialized text (Vandaele \& Raffo $2008 \mathrm{a}^{28}$ ). More studies are needed to better understand how to popularize adequately.

A strategy to be used by translators might be the following. First, it is necessary to become sensitive to the cognitive dissonance that is the landmark of conceptualisation indices: something is not really what it seems to be. The nerve is said to run, yet it does not move; the molecule seems to act as a person, yet it is inanimate; the mesencephalon has a roof, yet it is not the roof of a house. Second, the search for counterparts of non-predicative ICs and quasi-predicative ICs in the target language is not different from any terminological search. Third, the search for true predicative ICs in the target language should take into account the whole conceptual metaphor identified in the source text: is it expressed in the target culture-language? If not, is it possible to import the conceptual metaphor or is it preferable to find another one? If yes, what is the extent and the richness of the lexical network in the target culture-language? Finally, what is the role of the metaphorical expression: is it used strictly to conceptualize in a theoretical framework, does it have a rhetorical function, is it used for some popularization purpose? Taking into account all these parameters, it then becomes possible to make the best choice possible.

As a final word, I do hope that this overview will be helpful for anyone who is willing to introduce conceptual science metaphors in the classroom, to dig deeper into research or, as a practitioner, to use them. I believe that we are at an interesting point where a number of puzzling difficulties that perplexed us at the beginning have now been solved. At least, a certain level of coherence has been reached.

28. In Vandaele and Raffo (2008b), we cite the following example: the sentence "les décodeurs assemblent un collier d'acides aminés. À la fin de la phrase, le collier est complet : c'est une protéine" is almost impossible to understand because of the lack of the links that would allow the blend of the metaphors (decoding devices, necklace, sentence). If "translated" in a correct scientific French, this would give: "Une protéine est une chaîne ( $=$ collier/necklace) d'acides aminés assemblés par les ribosomes (= décodeurs/decoding device) qui lisent la suite de nucléotides (= phrase/sentence) des ARN messagers". 


\section{Acknowledgements}

I am very grateful to the Social Science and Humanities Research Council (SSHRC) for research grants I have received over the years (specifically: 2000-2004; 2004-2007; 2008-2012; 2015-2018). Students have received master scholarships from the SSHRC (M. Labelle [2006-2008]; M. Raffo [2008-2011]; E.-M. Gendron-Pontbriand [2011-2013]; M. Gingras-Harvey [2012-2014]), from the Coordenação de Aperfeiçoamento de Pessoal de Nível Superior (CAPES; Brasil; Paula Malaszkiewics, 2013) and from the Fundação de Amparo à Pesquisa do Estado do Rio Grande do Sul (FAPERGS; Bruna Steffen, 2016). PM et BS were cosupervised by Prof. Patricia Ramos Reuillard (dir., Universidade Federal do Rio Grande do Sul) and myself. Finally, I thank Douglas Rideout for their careful revision of the text.

\section{References}

ALMEISEIN, Jean-Claude. (2003) La sculpture du vivant - Le suicide cellulaire ou la mort créatrice. Paris: Seuil.

Alonso-Ramos, Margarita. (2003) "Éléments du frame vs. Actants de l'unité lexicale." MTT2003, Paris, 16-18 juin 2003, 12. p. Electronic version: <http:// www.grupolys.org/biblioteca/Alo2003a.pdf>.

ANDOR, József. (2010) "Discussing frame semantics: The state of the art - An interview with Charles J. Fillmore." Review of Cognitive Linguistics 8:1, pp. 157-176.

BARQUE, Lucie \& Anne-Laure Jousse. (2006) "Analysing Combinatorial Properties of Polysemic Lexical Units to Characterize Metaphorical Links." Proceedings XII EURALEX International Congress, Torino, Italia, 6-9 settembre 2006. European Association for Lexicography: Edizioni dell'orso Alessandria. Vol. 1, pp. 1102-1114.

BLACK, Max. (1962) Models and Metaphors. Ithaca: Cornell University Press.

BOERS, Frank \& Murielle Demecheleer. (1997) "A few metaphorical models in (Western) economic discourse." In: Wolf Andreas Liebert; Gisela Redeker \& Linda R. Waugh (eds.) 1997. Discourse and Perspective in Cognitive Linguistics. Amsterdam/Philadelphia: John Benjamins, pp. 115-129.

CAMEROn, Lynne. (2003) Metaphor in Educational Discourse. London / New York: Continuum.

Changeux, Jean-Pierre. (1983) Neuronal Man. The Biology of Man. Translated by Laurence Garney. Princeton: Princeton University Press, 1997.

Changeux, Jean-Pierre \& Paul Ricoeur. (1998) Ce qui nous fait penser. La nature et la règle. Paris: Odile Jacob. Cited in the English translation by Malcolm B. Debevoise: What makes us think? A neuroscientist and a philosopher argue about ethics, human nature, and the brain. Princeton: Princeton University Press, 2000. 
Collombat, Isabelle. (2003) "Le discours imagé en vulgarisation scientifique: étude comparée du français et de l'anglais." metaphorik.de 05/2003, 61 p. Electronic version available at: <http://www.metaphorik.de/sites/www.metaphorik.de/files/journal-pdf/05_2003_collombat.pdf>.

D’HUSLT, Lieven. (1992) "Sur le role des métaphores en traductologie contemporaine." Target 4:1, pp. 33-51.

ECO, Umberto. (1988) Sémiotique et philosophie du langage. Paris: Presses Universitaires de France, 2006.

Edelman, Gerald M. (1987) Neural Darwinism: the theory of neuronal group selection. New York: Basic Books.

EDELMAN, Gerald M. (1992) Bright air, brilliant fire: on the matter of the mind. New York: Basic Books.

Edelman, Gerald M. (2006) Second Nature: Brain Science and Human Knowledge. New York: Basic Books.

FAUCONNIER, Gilles \& Mark Turner. (1998) The way we think: conceptual blending and the mind's hidden complexities. New York: Basic Books.

FOX KELLER, Evelyn. (1999) Le rôle des métaphores dans les progrès de la biologie. Paris: Institut Sanofi-Synthélabo.

GeERAERTS, Dirk \& Hubert Cuyckens. (2010) "Introducing Cognitive Linguistics." In: Geeraerts, Dirk \& Hubert Cuyckens. 2012. The Oxford Handbook of Cognitive Linguistics. Electronic version available at: <http://10.1093/oxfor dhb/9780199738632.013.0001>.

GENDRON-PONTBRIAND, Eve-Marie. (2013) Modes de conceptualisation métaphorique et théorie de l'évolution: analyse textuelle et traduction. Montreal: Université de Montréal. Unpublished master thesis.

Gingras-Harvey, Mariane. (2014) Les modes de conceptualisation métaphorique en neuroanatomie : étude de la description anatomique du cervelet et de la moelle spinale. Montreal: Université de Montréal. Unpublished master thesis.

GoOSSENS, Louis. (1990) "Metaphtonymy: the interaction of metaphor and metonymy in expressions for linguistic action." Cognitive Linguistics 1, pp. 323-340.

GraY, Henry. (1918) Anatomy of the Human Body. Philadelphia: Lea \& Febiger. Bartleby.com, 2000. Electronic version available at: <http://www.bartleby. com/107/>.

Koller, Veronica. (2004) Metaphor and Gender in Buisiness Media Discourse. A critical cognitive study. New York: Palgrave macmillan.

LABElle, Mélanie. (2009) Les réseaux lexicaux nominaux témoignant de la conceptualisation métaphorique en anatomie. Montreal: Université de Montréal. Unpublished master thesis.

LAKOFF, Georges. (1987) Women, Fire, and Dangerous Things. Chicago: The University of Chicago Press. 
LAKOFF, Georges. (1993) "The contemporary theory of metaphor." In: Ortony A. (ed.) Metaphor and thought. $2^{\text {nd }}$ ed. Cambridge: Cambridge University Press, pp. 203-251.

LAKOFF, Georges. (2008) "The neural theory of metaphor." In: Gibbs R.W. Jr. (ed.) 2008. The Cambridge Handbook of Metaphor and Thought. Cambridge: Cambridge University Press, pp. 17-38.

LAKOFF, Georges. (2008) The political mind. New York: Penguin Books.

LAKOFF, Georges \& Mark Johnson. (1980) Metaphors We Live By - With a New Afterword. Chicago: The University of Chicago Press, 2003.

LEDDY, Thomas. (1995) "Metaphor and Metaphysics." Metaphor and Philosophy. 10:3, pp. 205-222.

LUBIN, Leslie. (2005) Étude des métaphores conceptuelles utilisées dans la description des structures anatomiques. Montreal: Université de Montréal. Unpublished master thesis.

MalaszKiewics, Paula Fernanda. (2013) Conceptualização metafórica da anatomia em português: arterias, veias e nervos. Porto Alegre: Universidade Federal do Rio Grande do Sul. Unpublished master thesis.

MalaszKiewics, Paula Fernanda; Sylvie Vandaele, \& Patricia Chittoni Ramos Reuillard. (2015) "Conceptualização metafórica da anatomia em português: arterias, veias e nervos." Tradterm 26, pp. 269-290.

MeL'ČUK, Igor A. (2004a) "Actants in Semantics and Syntax I: Actants in Semantics." Linguistics, 42: 1, 2004, 1-66.

MeL'ČUK, Igor A. (2004b) "Actants in Semantics and Syntax I: Actants in Syntax." Linguistics, 42: 2, 2004, 247-291.

MeL'ČUK, Igor A. (2012) Semantics - From meaning to text. Edited by David Berck and Alain Polguère. Amsterdam/Philadelphia: John Benjamins.

MeL'ČUK, Igor A. \& Alain Polguère. (2007) Lexique actif du français - Apprentissage du vocabulaire fondé sur 20000 dérivations sémantiques et collocations du français. Bruxelles: De Boeck Supérieur.

Mel'ČUK, Igor A. \& Alain Polguère. (2008) "Prédicats et quasi-prédicats sémantiques dans une perspective lexicographique." Lidil 37. Electronic version available at: $<$ http://lidil.revues.org/2691 >.

MirowSKI, Philip. (1989) More Heat than Light. Cambridge: Cambridge University Press. Cited in the French translation by Florence Briozzo \& Pierre Barreau: Plus de Chaleur que de Lumière. Paris: Economica, 2001.

MONTALT, Vicent \& Maria Gonzalez-Davies. (2007) Medical translation step by step: Learning by drafting. Manchester: St Jerome.

NOTARI, Christiane. (2010) Chomsky et l'ordinateur: approche critique d'une théorie linguistique. Toulouse: Presses Universitaires du Mirail.

OLIVEIRA, Isabelle. (2009) Nature et fonctions de la métaphore en science. L'exemple de la cardiologie. Paris: L'Harmattan. 
Ortony, Andrew, ed. (1993) Metaphor and Thought. Cambridge: Cambridge University Press.

RAFFO, Mariana. (2008) Vulgarisation et traduction: représentation discursive des notions scientifiques biomédicales en français et en espagnol. Montréal: Université de Montréal. Unpublished master thesis.

RAFFO, Mariana. (2016) "Translation and Popularization: Medical Research in the Communicative Continuum.” In: Sylvie Vandaele \& Pier-Pascale Boulanger (eds.) 2016. Science in Translation - Numéro spécial, Meta 61:HS, pp. 163-175.

Ricerur, Paul. (1975) La métaphore vive. Paris: Seuil, 1997.

Rojo Lopez, Ana Maria. (2011) "Distinguishing near-synonyms and translation equivalents in metaphorical terms." Review of Cognitive Linguistics 9:1, pp. 280-314.

SAMANIAGO FERnANDEZ, Eva. (2011) "Translation Studies and the cognitive theory of metaphor." Review of Cognitive Linguistics 9:1, pp. 262-279.

SHutova, Ekaterina; Simone Teufel \& Anna Korhonen. (2012) "Statistical Metaphor Processing." Computational Linguistics 39, pp. 1-52.

STEFFEN, Bruna. (2016) Conceitualização metafórica contrastiva em português e francês: anatomia dos músculos. Porto Alegre: Universidade Federal do Rio Grande do Sul. Unpublished master thesis.

TALmy, Leonard. (2000) "Fictive Motion in Language and 'Ception'." In: Talmy, Leonard 2000. Towards a cognitive semantics, Cambridge: MIT Press, pp. 99-176.

Temmerman, Rita. (2000) Towards New Ways of Terminology Description: The Sociocognitive Approach. Amsterdam: John Benjamins.

TEMmERMAN, Rita. (2002) "Metaphorical models and the translation of scientific texts." Linguistica Antverpiensia 1, pp. 211-226.

VANDAELE, Sylvie. (2000) "Métaphores conceptuelles et traduction biomédicale." In: Méjri, Salah; Taveb Baccouche; André Clas \& Gaston Gross (eds.) 2000. La traduction: théories et pratiques, Traduction humaine, traduction automatique, interprétation. Tunis: Publications de l'École Normale Supérieure de Tunis, pp. 393-404.

VANDAELE, Sylvie. (2003a) "Métaphores conceptuelles et traduction médical." TTR 15:1, pp. 223- 239.

VANDAELE, Sylvie. (2003b) "Fonctions lexicales et conceptualization métaphorique: l'alliance est-elle productive?" Séminaire OLST-RALI, Université de Montréal, le 14 mai 2003.

VANDAELE, Sylvie. (2004) "Deciphering metaphorical conceptualization in biomedicine: towards a systematic analysis." In: Rogers, Margaret \& Kurshid Ahmad (eds.) 2004. New Directions in LSP studies, Proceedings of the 14th European Symposium on Language for Special Purposes, 18 - 22 août 2003, pp. 195-202. 
VANDAELE, Sylvie. (2005) "Métaphores conceptuelles et fonctions lexicales: des outils pour la traduction médicale et scientifique" Actes du iiie congrès international de traduction spécialisée, Barcelone, Université Pompeu Fabra, 4 - 6 mars 2004, pp. 275-286.

VANDAELE, Sylvie. (2007) "Quelques repères épistémologiques pour une approche cognitive de la traduction. Application à la traduction spécialisée." Meta 52:3 pp. 129-145

VANDAELE, Sylvie. (2009) "Les modes de conceptualisation du vivant." In: Boucher, François-Emmanuël; Sylvain David \& Janusz Przychodzen (eds). 2009. Que peut la métaphore? Paris: L'Harmattan, pp. 187-207.

VANDAELE, Sylvie. (2013) "Du néologisme au domaine du savoir: le cas des sciences de la vie." Neologica, 7, pp. 157-185.

VANDAELE, Sylvie. (2015) "La recherche traductologique dans les domaines de spécialité: un nouveau tournant." Meta 60:2, pp. 209-237.

VANDAELE, Sylvie \& Marie-Claude Béland. (2012) "Les modes de conceptualisation des "unités d'hérédité" au xixe siècle." Linguistica Antverpiensia, 11, pp. 227-246.

VANDAELE, Sylvie, Sylvie Boudreau; Leslie Lubin \& Elizabeth Marshman. (2006). "La conceptualisation métaphorique en biomédecine: indices de conceptualisation et réseaux lexicaux," Glottopol, 8, pp. 73-94.

VANDAELE, Sylvie \& Leslie Lubin. (2005) "Approche cognitive de la traduction dans les langues de spécialité: vers une systématisation de la description de la conceptualization métaphorique," Meta, 20:2 pp. 415-431.

VAndAele, Sylvie \& Leslie Lubin. (2009). "Modes de conceptualisation et représentations fictives en anatomie." In: Dury, Pascaline; François Maniez; Nathalie Arlin \& Claire Rougemont (eds.) 2009. La métaphore en langues de spécialité. Grenoble: Presses Universitaires de Grenoble, pp. 61-81.

VANDAEle, Sylvie \& Mariana Raffo. (2007) "Revisiter l'équivalence: modes de conceptualization et réseaux lexicaux." XX congrès annuel de l'Association canadienne de traductologie, du 26 au 28 mai 2007, Saskatoon. Unpublished.

VANDAELE, Sylvie \& Mariana Raffo. (2008a) "Significations lexicales et notionnelles dans les domaines de spécialité." In: Maniez, François \& Pascaline Dur (eds.) 2008. Lexicologie et terminologie: histoire de mots, Lyon: Travaux du CRTT, pp. 249-268.

VANDAELE Sylvie \& Mariana Raffo. (2008b) "Conceptualización metafórica en el discurso científico y en el de divulgación." In: Morales O. (ed.) 2008. Actas del I Congreso International sobre Lenguaje y Asistencia Sanitaria, IULMA, Universidad de Alicante, 24-24 octobre 2007. Alicante: Universidad de Alicante (CD-ROM).

VANDAELE, Sylvie \& Mariane Gingras-Harvey. (2014) "Conceptual Metaphors in Medical Discourse: the Case of Neuroanatomy." In: The Language of Medicine: 
Science, Practice and Academia: An International Conference hosted by CERLIS Università degli studi di Bergamo, June 19-21, 2014. Unpublished.

VAndaele, Sylvie. (2017) "L'étudiant, l'enseignant et la technologie." Hermèneus. Revista de Traducción e Interpretación 19, pp. 1-17.

VAn Rijn-VAn TOngeren, Geraldine W. (1997) Metaphors in Medical Texts. Amsterdam/Atlanta: Rodopi.

VIDAL, Vanesa \& Maria Teresa Cabré. (2006) "La combinatoria léxica especializada: combinaciones metafóricas en el discurso de Genoma Humano." In: Maria Teresa Cabré; Rosa Estopà \& Carlos Tebé (eds.) 2006. La terminología en el siglo XXI: contribución a la cultura de la paz, la diversidad y la sostenibilidad: Actas del IX Simposio Iberoamericano de Terminología RITERM04. Barcelona: Institut Universitari de Lingüística Aplicada. Universitat Pompeu Fabra.

Vesalius, Andreas. (1543) La Fabrique du corps humain, livre I. In: La fabrique de Vésale et autres textes, première édition et traduction en français par Jacqueline Vons \& Stéphane Velut. 2014. Paris: BIU Santé.

Wright, Sue Ellen. (2011) "Scientific, Technical, and Medical Translation." In: Kirsten Malmkjær \& Kevin Windler (eds.) 2011. The Oxford Handbook of Translation Studies. Oxford: Oxford University Press.

ZethSEn, Karen. K. (2004) "Latin-based terms: True or false friends?" Target. International Journal of Translation Studies, 16:1, pp. 125-142.

\section{Image credits}

Figure 2

Left: Photo by Marc Giacone, under Wikicommons license (<https://upload. wikimedia.org/wikipedia/commons/6/62/Olives_noires_grecques.jpg >)

Right: Gray, Henry 1918 : plate 679, under Wikicommons license (<https:// commons.wikimedia.org/wiki/File:Gray679.png\#metadata>)

Figure 4

House: <https://commons.wikimedia.org/wiki/File\%3AMansard_(PSF).png>; by Pearson Scott Foresman [Public domain], via Wikimedia Commons Crane: <hhtps://commons.wikimedia.org/wiki/File\%3AGray194.png>. By Henry Gray. Henry Vandyke Carter [Public domain], via Wikimedia Commons 


\section{BIONOTE}

SYLVIE VANDAELE has trained and has had a career in both life sciences (PhD in molecular pharmacology) and translation. She is presently a full professor at the Université de Montréal (Canada) where she has been teaching biomedical translation since 2000. As a certified translator and terminologist (Ordre des traducteurs, terminologues et interprètes agréés du Québec), she defends with conviction the importance of exchanges between academia and the professional world. She combines her research on metaphor and in history of life sciences (supported by the SSHRC, Canada) with a great interest for the pedagogy of translation as well as for teaching, for which she won an award for teaching excellence in 2004. From 2008 to 2014, she was the director of Meta. She has published extensively on different dimensions of biomedical discourse and terminology from synchronic and diachronic perspectives, including metaphorical conceptualization (see < vandaele.biomettico.org $>$ ). Her current projects focus on the relationship between translation and the history of science. The <www. biomettico.org> website provides fellow translators and researchers with the results of her work.

Armée d'une double formation universitaire dans les sciences de la vie (doctorat en pharmacologie moléculaire) et en traduction, et ayant œeuvré successivement dans ces deux domaines, SYlVIE VANDAELE est professeure titulaire à l'Université de Montréal (Canada), où elle enseigne la traduction biomédicale depuis 2000. Par ailleurs traductrice et terminologie agréée auprès de l'OTTIAQ (Ordre des traducteurs, terminologues et interprètes agréés du Québec), elle défend avec conviction l'importance des échanges entre le monde universitaire et le milieu professionnel. Elle conjugue avec passion ses recherches sur la métaphore et en histoire des sciences de la vie (appuyées par le CRSH, Canada) et l'enseignement, pour lequel elle a obtenu un prix d'excellence en 2004. Elle a dirigé la revue Meta de 2008 à 2014 et a à son actif de nombreuses publications portant sur différentes dimensions du discours et de la terminologie en biomédecine en synchronie et en diachronie, notamment sur la conceptualisation métaphorique (voir <vandaele.biomettico.org >). Ses projets actuels concernent les relations entre la traduction et l'histoire des sciences. Le site <www.biomettico.org> met à la disposition de la communauté des traducteurs et des chercheurs le fruit de ses travaux. 